\title{
New Public Management and Governance: Quo Vadis?
}

\author{
Vasilios P. Andrikopoulos \& Amalia A. Ifanti \\ (Corresponding Authors) \\ Department of Educational Sciences and Early Childhood Education, University of Patras \\ Rio 26504, Patras, Greece \\ E-mail: vasileios.andrikopoulos@upatras.gr; ifanti@upatras.gr
}

Received: Aug. 6, 2020 Accepted: Sep. 17, 2020 Online published: Oct. 12, 2020

doi:10.5296/jpag.v10i3.17494 URL: https://doi.org/10.5296/jpag.v10i3.17494

\begin{abstract}
This paper seeks to provide an overview of the literature regarding contemporary public management and administration. For this purpose, New Public Management and New Public Governance principles and methods are explored, since they remain the dominant approaches to public management and governance regime. A systematic examination of the relevant discourse was carried out. Data analysis revealed that the theoretical schemes continue to emphasize the priority of management over public service. As a result, the New Public Service approach is revisited focusing primarily on the reinterpretation and reorientation of public service provision. This study enriches our theoretical and practical understanding by providing important reflections and insights about the organizational conditions of public sector reform that is proceeding nowadays.
\end{abstract}

Keywords: new public management, new public governance, new public service

\section{Introduction}

In the past few decades, administrative systems have been faced with serious problems of cohesion, coordination and exercise of power at the central level, on the one hand, and autonomy, fragmentation and separation, on the other. New Public Management has pervaded public sector giving rise to numerous changes related to the nature, construction and even the existence of public organizations. Although thirty years have passed since its advent and prevalence, research interest in New Public Management remains unchanged to date, as it appears to be the dominant approach in public administration (Hammerschmid, Van de Walle, Andrews, \& Mostafa, 2019; Haque, 2019).

The new millennium, however, hails the succession of New Public Management by the New Public Governance. This paradigmatic change in public administration and policy can be attributed to the specific changes taking place having not left unaffected New Public 
Management. These changes associated with globalization, the rapid evolution of Information and Communication Technologies as well as research data and results highlight the need for renewal and modernization of the New Public Management itself that brings focus on New Public Governance (Christensen \& Laegreid, 2001; 2017).

In this setting, this study seeks to reflect upon the literature review of New Public Management and New Public Governance, two approaches that remain strong through their methods and techniques revived and survived up to present. In particular, the present study attempts to shed light on the basic principles and techniques through the consideration and comparison of the New Public Governance with its preceded approach, i.e.: the New Public Management. In addition, the surrounding conditions and the conceptual framework of the new theoretical vehicle, in which the concept of leadership comes forth, as well as the refinement and redefinition of the concepts of organization and management under the influence of leadership theories, are examined. Data collection was drawn from a systematic examination of the relevant discourse officially published.

The structure of this work is split into four sections. Firstly, the New Public Management approach is presented and analyzed through its phases and main ideas developed. Secondly, the New Public Governance approach illustrates the key principles, the changes occurred in the public sector and the processes following the New Public Governance. In the third section, the on-going debate on the latest theoretical scheme is presented aiming at gaining insight on the conditions prevailing in public organizations nowadays. Finally, in the last section, some implications and concluding remarks are provided for future investigation.

\section{New Public Management: Overruling Public Administration}

New Public Management, as a new "dogma" for the public management, appeared for the first time in late 1970s, expressing more an institutional than a theoretical conceptual development. From this period onwards, there has been an intense and -at the same time- a rapid transition from public administration to public management. As this distinction is not particularly easy to use in practice, the two terms are often used interchangeably. Moreover, it is noted that the use of these concepts conceals, to a certain degree, an ideological approach to the functioning of the public service sector pervading the nature and the delivery system of services (Hood, 1990; Pollitt \& Boukaert, 2000; Laegreid, 2014).

New Public Management traces its origins in the United States of America during Reagan presidency (1981-1989). However, the New Public Management as a concept along with the new approach to public management was systematically developed and formed in Great Britain during Thatcher government (1979-1990). The new trend established suggests that the key responsibility of the public administration is to provide quality services and not to exercise power through democratic methods. Moreover, according to this approach, the role of the public administration as well as the outcomes of its actions are evaluated exclusively in terms of quality, with a central focus on meeting the needs of the public, namely the citizens-consumers of the public services (Gruening, 2001).

Thus, it seems that the diffusion of the concepts of New Public Management since late 1970s 
has contributed to the emergence of a new theoretical and conceptual framework for the overall administrative phenomenon at international level. In its most extreme form, the discussion about a new model of public administration included private sector techniques highlighting their relative superiority over those of the traditional public administration. The proponents of this new model are convinced that the adoption and application of such techniques will automatically lead to improved efficiency and effectiveness of public services (Pollitt, 2007; Christensen \& Laegreid, 2016).

The central ideas of New Public Management include the specific focus on the private sector management models aiming at increasing the practicality of managing its core services, removing the policy implementation from strategic planning and delegating it to the executives. New Public Management also promotes the decoupling of public services and their breakdown into key management units, cost reduction management and the strengthening of the role of the market, competition and contracts in the allocation of resources and the provision of services of general interest (Pollitt, 1990; Hood, 1991; Steinfeld, Koala, \& Carlee, 2019).

This fact seems to be no exception, since New Public Management is intertwined with the revival of the principles for scientific management postulated in early 1900s, leading many researchers and scholars to call this trend in public administration as neo-Taylorism. In parallel, the great emphasis placed on the managerial aspect of organization theory and practice along with the priority of the functional management and the systematic study in this field was considered to mirror the theory of Fayol also articulated at the beginning of $20^{\text {th }}$ century. This tendency in management theory and practice as well as the associated methods and techniques deployed in the public sector regime support the argumentation about the revival of the relevant theory of Fayol embedded in New Public Management discourse (Christensen \& Laegreid, 2002; Montana \& Charnov, 2008; Guthrie \& Peaucelle, 2015).

Later, drawing upon New Public Management, other methods such as Management by Objectives seemed to be utilized in public organizations. This can also be viewed as a revival, because the Management by Objectives theory had been proposed three decades before its uncovering in public sector. The original, authentic theory was initially presented in Peter Druckers's "Principles of management" published in 1954. Accordingly, Management by Objectives becomes a useful tool for managers and public administrators upgrading their status, as they are bestowed with much more authority, resulting in enhancing their role as well as facilitating the completion of the general aim of the organization (McMahon, 2013).

In the next phase, New Public Management is transformed into Managerialism, something that is considered by lot of scholars to be the downfall of the approach, since there has been an excessive, uncontrolled use of managerialistic techniques, tools and practices devoted to improve the public sector agencies and the services provided. In other words, it is claimed that Managerialism began to undermine itself inasmuch as to be self-abolished, in need of succession, advancement or evolution (Christensen \& Laegreid, 2001; Hesse, Hood, \& Peters, 2003). Consequently, the newly proposed type of public management has raised numerous negative critics with a clear focus on the structure of the new paradigm, in the sense that it is 
construed by a set of independent assumptions rather than consisting of a coherent theoretical approach (Pollitt \& Bouckaert, 2017).

These assumptions are multi-faceted, multi-dimensional in nature and incorporate ideological, administrative and research aspects. Additionally, the sphere of influence of the New Public Management is confined to the Anglo-Saxon, Australian-Asian and Scandinavian arcs. On the other side, traditional public administration, as an example of organizational structure and power-relation hierarchy that performs a set of functions and obeys different authorities, retains its prestige in countries with a strong bureaucratic tradition. In these countries, rule-of-law and democratic methods, hierarchical administrative and organizational structure and impersonal relationships continue to apply, whereas bureaucracy and centralized exercise of power remain firm pillars, on which agency management is based (Li \& Chung, 2020).

As far as the idea of leadership is concerned, several scholars underline that it is absent from the New Public Management debate, thus being indifferent as a concept and eliminated from the paradigm discussion. Hence, the impact of New Public Management on the public sector management appears to be particularly strong, so that the preferred leadership style is the managerial and entrepreneurial ones. At the last phase of its unfolding and implementation, New Public Management corresponds to the need for leadership giving rise to the progressive, transformational leadership (Morgan, Larsen, Bao, Wang, 2015; Pollitt, 2018). However, this trend is not linked to the New Public Management approach but to the apparent paradigm shift that coincides with the emergence of New Public Governance. Henceforth, New Public Management seems to be in need of a renewal, a fresh start and an uprising that is realized by transcending New Public Management or more accurately through a new paradigm hailing the era of New Public Governance (Hogan \& Howlett, 2015; Normand, 2018).

\section{New Public Governance: Transcending New Public Management}

In late 1990s, the decay of the New Public Management and the consequent need for its renewal called for its progressive replacement by the New Public Governance, signaling the transition to a new era. Some scholars, however, contend that this paradigmatic change has never been or taken place, arguing that New Public Governance emerges as a result of the New Public Management reconstruction process. Thus, it is pointed out that it is not a systematic change but rather a breach of the narrow limits of this approach by expanding its scope, while at the same time keeping the central core of its ideas, principles and methods in place and in any case dominant in public administration both institutionally and practically (Osborne, 2006; Christensen \& Laegreid, 2012).

This does not entail the complete withdrawal of New Public Management, which remains a significant approach for the role of the state and the private sector in public administration, but rather its inclusion in a wider context that emphasizes stakeholders' increasing participation in decision-making process. In parallel, the new environment generates negotiations between New Public Management and other approaches, thus questioning its coherence at the level of principles and methods related to risk taking and managing the uncertainty of the ever-changing, international environment (Bogdanor, 2005; Howlett, 2019). 
New Public Management has been associated with organizational changes that improve the ability to handle and accomplish tasks by delegating authority and granting power to separate, semi-autonomous organizations. However, limiting the role of the government initiated by a series of changes in the implementation of the New Public Management ideas did not deliver the expected results, as it was accompanied by the inability to deal with severe problems beyond organizations' boundaries and organizational levels of administration (Lægreid \& Verhoest, 2010; Pollitt \& Bockaert, 2011).

Thus, it should be noted that this approach has failed to alleviate the problems and difficulties of public administration, resulting in a strong need for replacement or paradigmatic shift and a gradual transition to a different approach, which would take into account the complexity of the modern era. At the international level, in the mid-2000s, there has been a shift towards the implementation of reforms, which inaugurate a new period characterized as "post-New Public Management era". This shift, both in theory and research alongside the field of policy making for public administration, meets the need for a stronger central government and the growing demand for innovative collaborative actions to tackle problems and difficulties that transcend national borders (Christensen \& Lægreid, 2010).

Governments around the globe start designing and implementing new forms of horizontal governance such as public-private partnerships (Osborne \& Plastrik, 2000; Hodge \& Greve, 2005), collaboration with stakeholders (McLaverty, 2002; Edelenbos \& Klijn, 2005) and other forms of citizen participation laid beneath the term New Public Governance. Arising as a more holistic model in public policy and leading to the shift in power relations, it pervades the notion of public management as long as the role of government changes dramatically (Castells, 2011).

Henceforth, governments rely heavily on the support provided by social actors and organizations in their efforts to implement policies designed to cope with increasingly complex problems. Many of these problems have conflicting values and addressing them requires governments to embrace horizontal interconnection and collaboration between organizations (Sorenson \& Torfing, 2007).

Furthermore, the demands for integrated services intensify the need for horizontal networks to be created through cooperation between different organizations. Taking it one step further, public governance requires the involvement of more than one agent in the policy making and implementation process. Private actors, social organizations and citizens are important factors that can interfere with or even reverse political interventions in public administration (Klenk \& Reiter, 2019).

A far as New Public Governance principles are concerned, it is maintained that it prioritizes achieving the goals of management by deploying strategies similar to New Public Management, the development of democratic governance and new forms of managing public institutions by creating administrative and policy networks, while prefixed ensuring a balance between the institutional characteristics of the administration, identifying -to some extent- the factors, processes, causes and effects of the relevant changes in the public sector (Christensen, 2012). 
In any case, the methods and techniques being developed and the practices applied seek to transform the organizational structures by shifting the role of public management. Thus, the concept of product delivered by public agencies is gradually being transformed into value added service and is the result of the proper functioning and governance of public bodies as well as the wider public sector. The new terms and conditions proposed and formulated to a certain extent shape the context in which the need to exercise leadership and to play a leading role in it emerges without however leaving or abolishing management either in its traditional form or in its newly advanced form (Dickinson, 2016).

At the same time, the old classical theories of public administration and the practices in question are not renounced, since the transformation of public administration is based on the development and improvement of existing systems. This means that the existing forms of the New Public Management are not abandoned but instead enriched and complemented by the philosophy, the ideological background as well as the set of beliefs in the New Public Governance discourse. Thus, it is noted that the New Public Governance incorporates elements such as the need for performance management deconstruction proposed as corrective interventions of the rigid nature of the New Public Management, with specific emphasis on managing social change within the agencies (Greve, Lægreid, \& Rykkja, 2016).

Therefore, an expanded approach is proposed, in which three approaches are intertwined, coexisting and even merged, i.e.: traditional bureaucratic public administration, management and governance, in the sense of forming a complex framework of needs and priorities. In other words, this approach refers to the increased need for rule-based management, objectives adhered to the principles of efficient and effective scientific management and networks created by the cooperation and synergies of a broader base of stakeholders and interest groups. Emanating both from the public and private sector, being active at the local, national, supranational and global level, these groups are dynamically involved in public policy and public sphere (Eriksson, 2019).

Consequently, changes in the field of public administration, public management and service delivery reflect wider changes occurring at the level of public policy, whose methods and techniques are subject to constant transformation. The links between central government, executives of organizations and non-governmental entities as well as other stakeholders and civil society actors inevitably affect the implementation of changes, with managers and management being constantly accountable. In this context, leadership is playing an important role mainly in such a complex framework with the high purpose of substantiating and materializing the improvement of the public sector agencies (Cheng, 2019).

Stakeholders' active engagement in public sector, as evidenced by the state acting as a coordinator, in accordance with the new role of enterprises, civil society and managers, manifests itself as a peculiar form of public policy arena. Each of the aforementioned factors interacts with the others developing relationships of conflict, complementation, confrontation, competition, or sometimes cooperation, seeking to maximize each and everyone's involvement and impact on organizations (Kristiansen, Dahler-Larsen, \& Ghin, 2019).

Nonetheless, their field of activity is neither predetermined nor strictly defined, thus 
contributing to the creation of a complex, multifaceted social context with characteristics ascribed to quasi-pluralism. However, these stakeholders do not cease to function like pressure or interest groups, especially taking into account the economic benefit of public service provision (Torfing \& Triantafillou, 2013; Haque, 2019).

Finally, at the end of New Public Management era, the interest for the nature and the orientation of governance, in terms of public management and administration expressed by the dilemma "to steer rather than to row" made or implied by some scholars (Peters, 1997; Denhardt \& Denhardt, 2000; Osborne \& Plastrik, 2000) resurges. Consequently, the calling for a new public service reoccurs in the public sector regime. The new approach that is to come forth supervenes on the managerial principles of effectiveness, efficiency and accountability being differentiated in their meaning and constituency.

\section{Beyond New Public Governance}

Denhardt \& Denhardt (2000, p.549) claimed that "public management has undergone a revolution". In fact, during the first decade of the new millennium, public administrators and managers begin to perceive their role as highly associated with entrepreneurial tasks preferring to steer rather than to row. Concomitantly, they appear to use the methods and techniques of organizational bureaucracy at a decreasing rate being concentrated on controlling and delivering services. Nevertheless, the following decade, namely in mid-2010s, the new leaner reinvented government, that has re-emerged through governance, is to be complemented by networks created by unions, non-profit organizations, the private sector and business initiatives seeking to find their place in the new governance milieu (Panyasiri, 2018).

This shift coincides with a process of demarcating new roles and boundaries of stakeholders, in order to grasp and provide innovation and public sector improvement with a primary focus on public interest substituted sometimes or incorporated into the individual interest. As a result, a number of highly important changes have been implemented differentiating the role of citizens as clients or consumers of public goods and services to a more proactive one. They bestow with the right or the ability to become providers of public services while maintaining their status as clients (Castells, 2011; Dickinson, 2016; Osborne et al., 2020).

These new conditions urge the reshaping of public administration, inasmuch as it appears to be in a direct connection and interrelated to public policy, initiating new forms of collective action, as well as new forms of collegiality. At the same time, it encourages the development and advancement of new approaches to public administration nurturing the idea of a New Public Service. This, in turn, eliminates the evaluation of the management work in terms of efficiency and effectiveness, therefore laying the foundations for assessing public sector institutions' benefit via its contribution to the well-being and satisfaction of citizens' needs (Osborne, 2018).

Thus, public sector services cease to be evaluated only in terms of performance and productivity, as there is an on-going discourse about the ethical and political appropriateness of public services. Besides, the successful management of organizations and the exercise of 
effective leadership do not limit to accountability and performativity towards customers or stakeholders, but more so through their responsibility for providing premium services, adhered to the code of ethics and abided by the principles of New Public Service (Dickinson, 2016).

The New Public Service goes beyond establishing new forms of activity and opens new horizons in public policy and administration, re-orienting public management and leadership and also clarifying the new priorities of governance. As in the case of its predecessors, New Public Service is not going to fully replace the approaches which is grounded on, but rather to alter and shake the internal consistency of New Public Management embedded in the New Public Governance. This seems to cause a turbulence and to challenge the sovereignty of the New Public Management and Governance until the balance of the new approach is rendered and its modes of governance exemplified (Denhardt \& Denhardt, 2015; Bryson, Crosby, \& Bloomberg, 2014).

\section{Discussion and Conclusion}

In this study, we sought to reflect and provide insight on the organizational conditions of the public sector, through a systematic review of the current literature around the New Public Management and New Public Governance. This investigation led us to trace the origins of New Public Service. The main aim of the study was to outline the changes in the field of public governance, which gave rise to the development of new theoretical schemes. Therefore, the main question which raised was what comes after the application of new principles in the public sector management and governance. New Public Management and New Public Governance principles, basic methods and theories embedded were presented.

A literature review on the topic revealed that the approach of New Public Management remains constantly dominant, while New Public Governance has been considered by many scholars to be a successive one, but mainly through evolution or reinvention of the New Public Management. Therefore, it can be argued that New Public Management retains its central position as a core managerial approach to public administration intertwined with the elevated status of public managers and executives. Being in charge of addressing the priorities and initiating specific strategies and practices, public managers assign and co-design along with the employees the tasks to be executed. One step further, these tasks must comply with the aims and objectives of the public organizations.

Nevertheless, managerial tasks, such as recontextualizing, reframing and re-interpreting the centrally planned policies, used to be performed by public managers and administrators in the era of New Public Management, were found to be insufficient for boosting innovation and risk-taking in public sector. What is more, coping with unprecedented changes and global insecurity associated with unpredictable natural and social phenomena (i.e.: natural disasters, terrorism, health crises, migration and refugee crisis), challenge the status quo and in many cases even the operation of public sector organizations. In this case, public organizations may be at high risk because of the violation of the regulations that have put into effect for the purpose of shielding public administration realm. 
As a result, a novel approach following New Public Management comes into view, namely New Public Governance, seeking to appeal to the intricacies of public administration, by extending the scope of interpretation and application of public policy. Thus, an expanded framework is formed, within which New Public Governance unfolds into a complex, multi-targeting and multi-level theoretical framework. This, in turn, can be characterized as a hybrid approach, building on and incorporating more than one aspect of public decision-making methods and strategies, as well as raising a need for alterations in public services' provision.

In other words, the New Public Management performance agenda focusing mainly on efficiency and effectiveness has displaced the traditional bureaucratic administrative model. At the same time, New Public Management having assimilated some of its elements rests beside the more holistic, three-sector approach comprised of executives, state and non-governmental entities and gives new meaning to efficiency and effectiveness. This change coincides with the generation of New Public Governance and necessitates the rising up of leadership.

Hence, a value-centred New Public Service approach, stemming from the transformation of public service management, draws the attention away from the performative nature of New Public Management to focus on the New Public Governance modes of control exerted in the reformed public administration. Therefore, the meaning of both efficiency and effectiveness is being reshaped as well as their new connotations in pursuing public sector governance.

Summing up, the consecutive transformations of public sector regime along with the gradually evolving methods of management as well as administration and governance theories lay the foundations for searching new perspectives in public administration and public service provision. Since this issue seems to be a significant key theme regarding public policy and the role of government in the contemporary society, the present study aspires to be a useful tool for deepening our understanding with regard to the complex structure and nature of the management systems.

As presented and discussed above, the management systems can affect and shape the reality of modern administration and governance. In this way, future research could enrich our theoretical and practical knowledge investigating how managerial and administrative contexts are being transformed in order to respond to the changes that are taking place globally. Moreover, research could also seek empirical data regarding the impact of these changes on the public service management. Further investigation can draw light on the way public interest is better served, paying tribute to the moral and political consequences as they have been assessed and described in the context of New Public Service.

\section{Acknowledgments}

We have no conflicts of interest. No funding source played a role in the preparation of this paper or in the decision to submit it for publication. Each author jointly contributed in the preparation of this paper. All authors have seen and approved the final version. 


\section{References}

Bogdanor, V. (Ed.). (2005). Joined-Up Government. Oxford: Oxford University Press. https://doi.org/10.5871/bacad/9780197263334.001.0001

Bryson, J. M., Crosby, B. C., \& Bloomberg, L. (2014). Public value governance: Moving beyond traditional public administration and the new public management. Public Administration Review, 74(4), 445-456. https://doi.org/10.1111/puar.12238

Castells, M. (2011). The rise of the network society. New Jersey: John Wiley \& Sons.

Christensen, T. (2012). Post-NPM and changing public governance. Meiji Journal of Political Science and Economics, 1(1), 1-11.

Christensen, T., \& Lægreid, P. (2001). New Public Management: The effects of contractualism and devolution on political control. Public Management Review, 3(1), 73-94. https://doi.org/10.1080/14616670010009469

Christensen, T., \& Leagreid, P. (2002). New public management: the transformation of ideas and practice. Aldershot: Ashgate.

Christensen, T., \& Lægreid, P. (2010). Increased complexity in public sector organizations: the challenges of combining NPM and post-NPM. In P. Lægreid \& K. Verhoest (Eds.), Governance of public sector organizations: proliferation, autonomy and performance (pp. 255-278). Basingstoke: Palgrave Macmillan. https://doi.org/10.1057/9780230290600_13

Christensen, T., \& Lægreid, P. (2012a). Administrative reforms in western democracies. In B. G. Peters \& J. Pierre (Eds.), The Sage handbook of public administration (pp. 577-589) London: Sage Publications. https://doi.org/10.4135/9781446200506.n38

Christensen, T., \& Lægreid, P. (2016). The Ashgate research companion to new public management. London: Routledge. https://doi.org/10.4324/9781315613321

Christensen, T., \& Laegreid, P. (2017). Transcending new public management: The transformation of public sector reforms. London: Routledge. https://doi.org/10.4324/9781315235790

Cheng, Y. (2019). Exploring the role of nonprofits in public service provision: moving from coproduction to co-governance. Public Administration Review, 79(2), 203-214. https://doi.org/10.1111/puar.12970

Denhardt, J. V., \& Denhardt, R. B. (2015). The new public service revisited. Public Administration Review, 75(5), 664-672. https://doi.org/10.1111/puar.12347

Denhardt, V., \& Denhardt, R. B. (2011). The New Public Service: serving, not steering (3rd ed.). Armonk, NY: M. E. Sharpe.

Dickinson, H. (2016). From New Public Management to New Public Governance: The Implications for a 'New Public Service'.' In J. Butcher \& D. Gilchrist (Eds.), The Three Sector 
Solution: Delivering Public Policy in Collaboration with Not-For-Profits and Business. Canberra, Australia: The Australian National University Press.

Drucker, P. (1954). The principles of management. New York: Harper-Collins Publishers.

Edelenbos, J., \& Klijn, E. H. (2005). Managing stakeholder involvement in decision making: A comparative analysis of six interactive processes in the Netherlands. Journal of Public Administration Research and Theory, 16(3), 417-446. https://doi.org/10.1093/jopart/mui049

Eriksson, E. M. (2019). Representative co-production: broadening the scope of the public service logic. Public Management Review, 21(2), 291-314. https://doi.org/10.1080/14719037.2018.1487575

Greve, C., Laegreid, P., \& Rykkja, L. H. (Eds.). (2016). Nordic administrative reforms: Lessons for public management. London: Palgrave McMillan. https://doi.org/10.1057/978-1-137-56363-7

Gruening, G. (2001). Origin and theoretical basis of New Public Management. International Public Management Journal, 4(1), 1-25. https://doi.org/10.1016/S1096-7494(01)00041-1

Guthrie, C., \& Peaucelle, J. L. (2015). Henri Fayol, the Manager. London: Pickering \& Chatto. https://doi.org/10.4324/9781315654546

Hammerschmid, G., Van de Walle, S., Andrews, R., \& Mostafa, A. M. S. (2019). New public management reforms in Europe and their effects: Findings from a 20-country top executive survey. International Review of Administrative Sciences, 85(3), 399-418. https://doi.org/10.1177/0020852317751632

Haque, M. S. (2019). The changing foundations of public administration: from identity to modernity to diversity. International Review of Public Administration, 1, 1-8. https://doi.org/10.1080/12294659.2019.1632042

Hesse, J. J., Hood, C., \& Peters, B. G. (2003). Paradoxes in public sector reform: soft theory and hard cases. Berlin: Duncker and Humblot. https://doi.org/10.3790/978-3-428-50798-6

Hodge, G. A., \& Greve, C. (2005). The challenge of public-private partnerships: Learning from international experience. Cheltenham: Edward Elgar Publishing. https://doi.org/10.4337/9781845428082

Hogan, J., \& Howlett, M. (2015). Policy paradigms in theory and practice. Hampshire: Palgrave Macmillan. https://doi.org/10.1057/9781137434043

Hood, C. (1990). De-Sir Humphreyfying the Westminster model of bureaucracy: a new style of governance? $\quad$ Governance, $\quad 3(2), \quad 205-214$. https://doi.org/10.1111/j.1468-0491.1990.tb00116.x

Hood, C. (1991). A public management for all seasons?. Public Administration, 69(1), 3-19. https://doi.org/10.1111/j.1467-9299.1991.tb00779.x

Howlett, M. (2019). Designing public policies: Principles and instruments. London: 
Routledge. https://doi.org/10.4324/9781315232003

Klenk, T., \& Reiter, R. (2019). Post-New Public Management: reform ideas and their application in the field of social services. International Review of Administrative Sciences, 1 , 3-10. https://doi.org/10.1177/0020852318810883

Kristiansen, M. B., Dahler-Larsen, P., \& Ghin, E. M. (2019). On the dynamic nature of performance management regimes. Administration \& Society, 51(6), 991-1013. https://doi.org/10.1177/0095399717716709

Lægreid, P. (2014). Accountability and new public management. In M. Bovens, R. E. Goodin, \& T. Schillemans (Eds.), The Oxford handbook of public accountability. Oxford, UK: Oxford University Press.

Lægreid, P., \& Verhoest, K. (2010). Governance of public sector organizations: Proliferation, autonomy and performance. Netherlands: Springer. https://doi.org/10.1057/9780230290600

Li, J., \& Chung, K. (2020). Decomposing Isomorphism: What Drives Similarity in the Adoption of New Public Management?. Administration \& Society, 52(3), 375-404. https://doi.org/10.1177/0095399718811307

Montana, P. J., \& Charnov, B. H. (2008). Management. New York: Barron's.

Morgan, D. F., Larsen, G. L., Bao, G., \& Wang, X. (2015). A value-based global framework for New Public Governance. In D.F. Morgan \& B.J. Cook (Eds.), New Public Governance: a regime-centered perspective (pp. 48-62). New York: Routledge. https://doi.org/10.4324/9781315702100

McLaverty, P. (2002). Civil society and democracy. Contemporary Politics, 8(4), 303-318. https://doi.org/10.1080/13569770216068

Osborne, D., \& Plastrik, P. (2000). The reinventor's fieldbook: Tools for transforming your government. San Francisco, CA: Jossey Bass.

Osborne, S. P. (2006a). Introduction: The (new) Public Governance: a suitable case for treatment?. In S. P. Osborne (Ed.), The New Public Governance? Emerging perspectives on the theory and practice of public governance (pp.1-16). London: Routledge.

Osborne, S. (2018). From Public Service-dominant Logic to Public Service Logic: Are Public Service Organizations Capable of Co-production and Value Co-creation?." Public Management Review, 20(2). 225-231. https://doi.org/10.1080/14719037.2017.1350461

Osborne, S., Brandsen, T., Mele, V., Nemec, J., van Genugten, M., \& Flemig, S. (2020). Risking innovation. Understanding risk and public service innovation- evidence from a four-nation study. Public Money \& Management, 40(1), 52-62. https://doi.org/10.1080/09540962.2019.1621051

Panyasiri, C. (2018). A Comparative Analysis of Contemporary Public Management Concepts in Thailand. Journal of Public Administration and Governance, 8(4), 155-171. https://doi.org/10.5296/jpag.v8i4.13708 


\section{Macrothink}

Journal of Public Administration and Governance

ISSN 2161-7104

2020, Vol. 10, No. 3

Peters, B. G. (1997). Shouldn't Row, Can't Steer: What's a Government to do?. Public Policy and Administration, 12(2), 51-61. https://doi.org/10.1177/095207679701200205

Pollitt, C. (1990). Managerialism and the public services: The Anglo-american experience. Oxford: Basil Blackwell.

Pollitt, C. (2007b). The New Public Management: An overview of its current status. Administration and Public Management Review, 8, 110-115. https://doi.org/10.1080/09540962.2017.1407129

Pollitt, C., \& Bouckaert, G. (2000). Public management reform: a comparative analysis. Oxford: Oxford University Press.

Pollitt, C., \& Bouckaert, G. (2011). Public management reform: A comparative analysis New Public Management, Governance and the neo-Weberian state. Oxford: Oxford University Press.

Pollitt, C., \& Bouckaert, G. (2017). Public management reform: A comparative analysis-into the age of austerity. UK: Oxford University Press.

Pollitt, C. (2018). Performance management 40 years on: a review. Some key decisions and consequences. Public Money \& Management, 38(3), 167-174. https://doi.org/10.1080/09540962.2017.1407129

Sorenson, E. J., \& Torfing, J. (2007). Theories of democratic network governance. Cheltenham: Edward Elgar. https://doi.org/10.1057/9780230625006

Steinfeld, J., Koala, K., \& Carlee, R. (2019). Contracting for public stewardship in public-private partnerships. International Journal of Procurement Management, 12(2), 135-155. https://doi.org/10.1504/IJPM.2019.098549

Torfing, J., \& Triantafillou, P. (2013). What's in a name? Grasping new public governance as a political-administrative system. International Review of Public Administration, 18(2), 9-25. https://doi.org/10.1080/12294659.2013.10805250

\section{Copyright Disclaimer}

Copyright for this article is retained by the author(s), with first publication rights granted to the journal.

This is an open-access article distributed under the terms and conditions of the Creative Commons Attribution license (http://creativecommons.org/licenses/by/4.0/). 